\title{
LOS MITOS DE FAUSTO Y DON JUAN. ANÁLISIS COMPARATIVO DE EL BURLADOR DE SEVILLA DE TIRSO DE MOLINA Y EL FAUSTO DE CHRISTOPHER MARLOWE ${ }^{1}$
}

\author{
Elena Nicolás Cantabella \\ Universidad de Murcia
}

\section{INTRODUCCIÓN}

Si existen en la cultura europea dos mitos surgidos de la literatura con mayor arraigo y proyección, éstos son los de Fausto y Don Juan. Sólo con repasar el innumerable catálogo de obras que se han ocupado de plasmar dichos personajes nos podemos hacer una idea de la tremenda influencia que han tenido, siguen teniendo y, seguramente, tendrán en las artes europeas.

De Fausto podemos destacar obras teatrales tan importantes como las dos partes del Fausto de Goethe (Alemania, 1806, 1832), novelas como el Fausto de Turgueniev

1 Recibido: 20/I/2011 Aceptado: 13/III/2011 
(Rusia, 1853), Doctor Fausto de Thomas Mann (Alemania, 1947), o revisiones como El retrato de Dorian Gray de Oscar Wilde (Inglaterra, 1891), El fantasma de la ópera de Gaston Leroux (Francia, 1910), El maestro y Margarita de Mijaíl Bulgákov (Rusia, 1929 - 1940), todas ellas dentro también del género novelesco, La barca sin pescador de Alejandro Casona (España, 1945), en teatro, y, dentro del género lírico, el poema de Baudelaire "Chatiment de L'Orgueil", o la atípica recreación del mito en el poema de la literatura gauchesca Fausto, impresiones del gaucho Anastasio el Pollo en la representación de la Ópera, del argentino Estanislao del Campo (1886). Asimismo, otras artes también han tratado el mito del hombre que vende su alma al diablo para alcanzar el conocimiento. Recordemos la más importante adaptación musical, la ópera de Gounod, Fausto (Francia, 1854), o la legendaria película del expresionista alemán Murnau, basada en la obra de Goethe, Fausto (1926). Y esto sólo por citar algunas de las más importantes revisiones del mito.

De la misma manera, el mito de Don Juan arraigó en la cultura europea desde su fijación definitiva a manos de Tirso de Molina, El burlador de Sevilla y convidado de piedra (1630), para ofrecernos constantes versiones y adaptaciones, de entre las que cabe destacar, entre otras, Don Juan o el festín de piedra de Molière (Francia, 1665), No hay plazo que no se cumpla ni deuda que no se pague o convidado de piedra de Antonio de Zamora (España, 1714), Don Juan Tenorio o El libertino castigado de Carlo Goldoni (Italia, 1730) o la obra que transforma el mito y lo fija como arquetipo, por cierto bastante distanciado del de Tirso, Don Juan Tenorio de José Zorrilla (España, 1844), todas ellas dentro del género teatral. Asimismo, dentro de la poesía, no podemos olvidar el Don Juan de Lord Byron (Inglaterra, 1821), ya que esta obra es la prueba del poder de atracción que tiene este mito para los románticos. Y para finalizar este breve muestrario, debemos mencionar la magnífica ópera de Mozart Don Giovanni (Austria, 1787) con libreto de Lorenzo Da Ponte.

Precisamente por ser dos mitos que tanto han inspirado a novelistas, poetas, dramaturgos, músicos, cineastas... de la tradición europea, es necesario hacer una confrontación de ambos, para la cual vamos a utilizar la primera versión de cada uno de ellos, esto es, vamos a analizar y a comparar El Burlador de Sevilla de Tirso de Molina $(1613,1630)^{2}$ con La trágica historia de la vida y muerte del doctor Fausto de Christopher Marlowe $(1592,1604){ }^{3}$ Las razones que nos llevan a creer que debemos confrontar ambas obras son las siguientes: en primer lugar, se trata de dos obras que recogen por primera vez dos mitos que existían en la tradición popular; en segundo lugar, la fecha de redacción de ambas obras es muy cercana, pues tan sólo median veinte años entre la

\footnotetext{
2 La primera fecha es la posible fecha de redacción de la obra y la segunda es la fecha de impresión.
}

3 Ver nota 1. 
obra de Marlowe y la de Tirso; en tercer lugar, Fausto y Don Juan son los dos grandes mitos europeos que, además sufren una misma suerte en el período romántico; ambos personajes son fuente de inspiración para los escritores de este período, que revisan estos mitos y los reformulan dándoles la forma definitiva mediante la que han llegado a nosotros; en cuarto lugar, son arquetipos que siguen siendo productivos en todas las artes, sobre todo en el mundo del cine, en el que están muy presentes; en quinto lugar y como causa del anterior punto, ambos ejercen un gran poder de atracción; y en sexto y último lugar, porque el análisis comparativo de ambas obras supone, además, una confrontación de dos modelos teatrales de la misma época, pero de diferentes países, lo que puede ayudarnos a encontrar semejanzas y divergencias entre ambos planteamientos. ${ }^{4}$

\section{GENEALOGÍA DE FAUSTO Y DON JUAN}

Para comenzar el estudio comparativo debemos hacer un recorrido por la formación de ambos mitos antes de llegar a su fijación escrita por parte de los dramaturgos del siglo XVII.

El personaje de Fausto tiene como antecedente histórico un personaje llamado Georgius Faustus (1480 - 1540), que vivió en las ciudades universitarias de Wittenburg, ${ }^{5}$ Erfurt e Ingolstadt, y que se dedicó a la medicina, la astrología y la alquimia. Hay datos de sus contemporáneos que aseguran que practicaba la nigromancia, que había intentado volar y que murió despedazado por un demonio en forma de perro. ${ }^{6}$ Este personaje genera un sinfín de leyendas a principios del siglo XVI, que son recogidas en un volumen que aparece en Alemania con el título de Historia von D. Iohan Fausten en 1587, de autor anónimo, editado por J. Spiess, y más conocido como Faust - Buch. La obra se extiende por Europa rápidamente y enseguida es traducida al inglés. ${ }^{7}$

Pero, aunque la leyenda surge a principios del siglo XVI debemos señalar que la idea del hombre que vende su alma al diablo por alcanzar el conocimiento nos remite a la Biblia, al libro del Génesis, ya que se trata de la historia de la expulsión de Adán y Eva del Paraíso a causa de su pecado de querer adquirir el conocimiento pleno, es

\footnotetext{
4 Las ediciones utilizadas han sido la de Julio César Santoyo y José Miguel Santamaría: C. Marlowe, La trágica historia de la vida y la muerte del doctor Fausto, Madrid, Cátedra, 2001, y la de Francisco Florit Durán: T. Molina, El burlador de Sevilla, Madrid, Debolsillo, 2003.

5 Julio César Santoyo y José Miguel Santamaría recuerdan en su edición de la obra, C. Marlowe, La trágica historia de la vida y la muerte del doctor Fausto, Madrid, Cátedra, 2001, p. 51., que ésa es la misma ciudad en la que estudian Lutero y Hamlet.

6 Tomado de Martínez López, M., Y seréis como dioses. Estudio sobre Christopher Marlowe y doctor Fausto, Granada, Universidad de Granada, 1995, pp. 83-84.

7 No se conserva dicha traducción.
} 
decir, de ser como dioses por medio del fruto prohibido, como podemos observar en la siguiente cita:

Sólo del fruto del árbol que está en medio del jardín nos ha dicho Dios: No comáis de él, ni lo toquéis siquiera, bajo pena de muerte. Entonces la serpiente dijo a la mujer: ¡No, no moriréis! Antes bien, Dios sabe que en el momento en que comais se abrirán vuestros ojos, y seréis como dioses, conocedores del bien y del mal. ${ }^{8}$

La motivación que mueve al Fausto de Marlowe a pactar con el diablo es la de alcanzar conocimientos, un poder sobrehumano más allá del que poseen los reyes; Fausto quiere rivalizar con el mismo Dios, como podemos observar en el siguiente fragmento de su discurso:

¡Oh, qué mundo de riquezas y placeres,/ de poder, honor y omnipotencia/ se le ofrece al estudioso maestro!/ Todo cuanto bulle entre los inmóviles polos/ estará a mi servicio: sólo se acata a los reyes/ y emperadores en sus respectivos dominios,/ pero no alcanzan a levantar el viento/ ni a rasgar las nubes;/ el poder del iniciado, sin embargo, los sobrepasa/ y se extiende hasta los confines mismos/ de la mente humana: un buen mago es un dios poderoso. ${ }^{9}$

Fausto, como podemos comprobar, quiere ser un dios. Por ello, hay una relación entre él y el fruto prohibido que comieron Adán y Eva, aunque, por supuesto, el Fausto de Marlowe, a diferencia de Adán y Eva y del de Goethe, no necesita ser tentado por Mefistófeles, sino que ha tomado su decisión sin necesidad de intermediarios.

Pero, además de esta influencia bíblica, nos encontramos con otra: la relación que une a Fausto con el Príncipe de las Tinieblas, Lucifer. El ángel más bello se rebela contra Dios porque no quiere servir al hombre, que va a ser creado y, por ello, desafía a Dios intentando equipararse a él y lanzando su terrible "Non serviam», ${ }^{10}$ "no te serviré», que es exactamente lo mismo que va a hacer Fausto, rebelarse contra Dios proclamando que ya no estará al servicio de Dios, sino de sí mismo, lo que le conduce a su caída y condena final.

También en la mitología nos encontramos con ecos anticipados de lo que va a ser el mito de Fausto. En primer lugar debemos destacar el personaje de Ícaro, hijo de Dédalo, quien al huir de Creta con unas alas que su padre le había fabricado con cera, asciende demasiado para contemplar el sol, el cual derrite sus alas cayendo Ícaro

\footnotetext{
8 Génesis, 3, 3-5. La Biblia, edición de Evaristo Martín Nieto, Madrid, San Pablo, 1989. De fructu vero ligni, quod est in medio paradisi, praecepit nobis Deus, ne comederemus et ne tangeremus illud, ne moriamur. Dixit autem serpens ad mulierem: "Nequaquam morte moriemini! Scit enim Deus quod in quocumque die comederitis ex eo, aperientur oculi vestri, et eritis sicut Deus scientes bonum et malum".

9 C. Marlowe, op. cit., p. 54.

10 Jeremías, 2, 20.
} 
al mar y muriendo, dando nombre al mar de Icaria. ${ }^{11}$ Ícaro representa el castigo que recibe aquél que intenta volar demasiado alto, ya que las alturas son patrimonio de los astros y de los dioses, no de los simples mortales. El mito de Ícaro está presente en la obra de Marlowe, puesto que, al inicio de ésta, el coro compara el ansia de sabiduría y poder de Fausto y su posterior caída con la de Ícaro, como podemos comprobar en el siguiente fragmento:

Hasta que ebrio de ciencia y presunción/ sus alas de cera volaron a zonas prohibidas/ y el fuego del cielo determinó su caída. ${ }^{12}$

Otro mito greco-latino que también puede relacionarse con Fausto y que posee un carácter similar al de Ícaro es el de Faetonte, quien le pidió a su padre el Sol conducir su carro durante un día, pero no pudo gobernar los caballos y se precipitó al ser alcanzado por un rayo que lanzó Júpiter.13

El último mito de la tradición clásica en el que podemos rastrear los elementos de Fausto es el de Prometeo, el inmortal amigo del ser humano que decide engañar a Júpiter en dos ocasiones: en la primera, mediante el engaño consigue que en los sacrificios el hombre se quede con la mejor parte del buey, quedando la piel, la grasa y los huesos para los dioses; mientras que en la segunda, con una lanza muy alta consigue robar el fuego que el padre de los dioses había negado a los hombres. Prometeo es también castigado con todos los males del mundo a causa de la mujer, Pandora, que Júpiter envía.

Ícaro (como también Faetonte) y Prometeo son dos ejemplos míticos de rebelión contra Dios y, según Martínez López, Fausto «comparte» con ello:

su afirmación de individualidad, su rebelión contra la contingencia de lo humano y su ilusión por destruir la idea de límite. ${ }^{14}$

Éste sería, pues, un breve recorrido por las fuentes y antecedentes de la obra de Marlowe.

En lo concerniente a Don Juan, podemos señalar sus antecedentes también en la tradición popular medieval. Es muy importante indicar que Tirso une en su obra dos motivos medievales que se conocían desde antiguo: el motivo del burlador y el

11 Ovidio, Metamorfosis, Madrid, Cátedra, 1995, Libro VIII, pp. 474-476.

12 C. Marlowe, op. cit., p. 52.

13 Ovidio, op. cit., Libro II, pp. 235-251.

14 M. Martínez López, op. cit., p. 85. 
del convidado de piedra. En cuanto al motivo tradicional del burlador, mucho se ha discutido sobre dónde puede encontrarse el antecedente de este personaje en nuestro teatro, dando para ello respuestas muy variadas. Lo realmente importante es que este motivo estaba presente en la cultura y que era conocido. El otro motivo, el del convite macabro, se encontraba también en la tradición popular medieval, como podemos observar en un romance tradicional del que existen muchas versiones en todos los puntos de la geografía española y que cuenta como un "galán", que iba a la iglesia a oír misa, se encuentra con una calavera, a la que propina un puntapié y de la que se mofa invitándola a cenar en su casa. El galán se asusta cuando la calavera le dice que es ella la que le invita a cenar esa noche. El galán regresa a su casa con mucho miedo y, estando allí, llaman a la puerta; se trata de la calavera que va a llevarse al galán a una sepultura abierta para que cene con él, pero, como el galán se encomienda a Dios, la calavera decide liberarlo de tan horrible invitación. ${ }^{15}$

Una propuesta más arriesgada es la que vincula a don Juan con el mito griego de Ixión, propuesta de José Ricardo Morales. ${ }^{16}$ Ixión es un rey de Tesalia, que se casa con Día, hija del rey Deyoneo, y al que mata al lanzarlo en unas brasas ardientes puesto que le había reclamado todos los presentes que Ixión le había prometido al pedirle la mano de su hija. Por otra parte, la segunda burla del rey de los lapitas es contra Zeus, que era el único que se había apiadado de él tras el horrible crimen. Ixión desea unirse con Hera, lo que no llega a suceder porque Zeus crea una nube con la forma de la diosa, que es a la que se une Ixión. Por todo ello, Ixión es castigado por Zeus a dar vueltas eternamente (ya que Ixión era inmortal) en una rueda envuelta en llamas. ${ }^{17}$

Para Morales, tanto Ixión como don Juan representan la juventud, es decir, la fogosidad juvenil, el desprecio por los ancianos, su despreocupación ante la muerte, que es observada como algo lejano. Por ello cree que Ixión es el precedente mítico de don Juan, ya que: es un burlador, que pretende «destruir la institución del matrimonio arcaico»; mata a su suegro, lo que él identifica con la muerte de don Gonzalo de Ulloa a manos de don Juan en la obra de Tirso. También compara finalmente a ambos personajes mediante el motivo del fuego, ya que en los dos castigos aparece dicho elemento.

Como hemos visto, en la genealogía de ambos personajes encontramos puntos en común. Los dos mitos poseen raíces que se hunden en la mitología clásica; hemos señalado el vínculo existente entre Fausto y Faetonte, Ícaro y Prometeo, y el de don Juan

\footnotetext{
15 El romance está en R. Menéndez Pidal, «Sobre los orígenes del convidado de piedra», Estudios literarios, Madrid, Espasa-Calpe, 1920, p. 92.

16 J. R. Morales, «El precedente mítico de don Juan», Cuadernos de Teatro Clásico, 2, 1988, pp. 11-16.

17 P. Grimal, Diccionario de mitología griega y romana, Barcelona, Paidós, 1981, pp. 293-294.
} 
con Ixión, aunque ésta es una aportación más novedosa. También debemos destacar la gran importancia del imaginario medieval en ambas obras; la obra de Marlowe es una mezcla entre elementos renacentistas y elementos medievales, que la acercan a las moralidades inglesas de la Edad Media. En el caso de don Juan la influencia es todavía más notoria, ya que el mito se va formando y transmitiendo en los diversos romances medievales. Lo que sí es cierto es que ambos mitos recorren un largo camino en el que se gestan hasta llegar a su momento de madurez, cuando Marlowe y Tirso los recogen.

\section{FAUSTO VS DON JUAN}

Tanto el personaje de Fausto de Marlowe como el don Juan de Tirso comparten una serie de rasgos que es preciso analizar y comentar detenidamente para poder establecer lazos entre ambas obras.

El primer rasgo que ambos personajes comparten es el de la soberbia o la vanidad. En el caso de Fausto percibimos este rasgo en el propio tema central de la obra, que no es otro que el conflicto entre la salvación en la ley de Dios frente a la condenación en el placer y la soberbia, según la edición de la obra de Julio César Santoyo y José Miguel Santamaría. Fausto elige el cuerpo rechazando el alma, el tiempo rechazando la eternidad y el mundo rechazando la religión, y en esta elección se muestra soberbio, pues rechaza a Dios sintiendo que casi puede equipararse a él, como ya habían hecho sus antecedentes Adán y Eva, Ícaro, Faetonte, Prometeo, Simón el Mago, Teófilo de Siracusa, Cipriano de Antioquía o Georges Faust.

Encontramos esta actitud soberbia en la necesidad que siente el personaje de dominar artes que le están vedadas, ya que sólo son propias de Dios, como cuando afirma:

Si pudieras hacer vivir eternamente a los mortales/ o, si muertos, pudieras devolverlos a la vida,/ entonces podrías tener algo en esta profesión. ${ }^{18}$

Fausto siente que su conocimiento y poderes son limitados y aspira a conocer y a dominar saberes que son exclusivos de Dios, como lo son la inmortalidad y el poder de resucitar a los muertos.

Esta actitud de pretender sobrepasar los límites que le han sido concedidos, puede observarse en toda la escena segunda del acto primero, cuando Fausto se queja de los límites a los que ha llegado en las materias que ha estudiado y expresa su

18 C. Marlowe, op. cit., p. 53. 
necesidad de ir más allá de ellos. Todo ello podemos ejemplificarlo con el siguiente fragmento:

En cambio, estas metafísicas de teúrgo/ y estos libros nigrománticos son gloriosos./ ¡Líneas, círculos, signos, letras y caracteres!/ ¡Estos son los que Fausto más desea!/ ¡Oh, que mundo de riquezas y placeres,/ se le ofrece al estudioso maestro! Todo cuanto bulle entre los inmóviles polos/ estará a mi servicio: sólo se acata a los reyes/ y emperadores en sus respectivos dominios,/ pero no alcanzan a levantar el viento/ ni a rasgar las nubes;/ el poder del iniciado, sin embargo, los sobrepasa/ y se extiende hasta los confines mismos/ de la mente humana: un buen mago es un dios poderoso. ${ }^{19}$

En este parlamento vemos cómo Fausto se ha decantado por las artes secretas y prohibidas de la magia para poder alcanzar un conocimiento mayor que el de los reyes, sólo equiparable a los dioses. Pretender ser un «dios poderoso» representa una actitud de soberbia, la misma que caracteriza a Lucifer y, además, supone una blasfemia.

Esta obstinación ciega en dominar los elementos y alcanzar un conocimiento mayor se observa también en la terquedad del personaje en manifestar sus nuevos poderes, como podemos observar en la siguiente intervención de Fausto:

porque antes de dormir he de ver hoy cuál es mi poder./ Esta noche haré un conjuro, así me cueste la vida. ${ }^{20}$

Toda esta soberbia conduce a Fausto a sellar un pacto con el diablo, mediante el que pretende ser «el gran emperador del mundo» ${ }^{21}$ en sus propias palabras.

Por su parte, una de las características más marcadas del don Juan de Tirso de Molina es precisamente la soberbia que derrocha durante toda la obra y que no cesa hasta que no es castigado.

Soberbio, jactancioso, infame, irrefrenable en su sexualidad, vanidoso, corrompido, contumaz, colérico, arrogante, ansioso de fama, orgulloso de su linaje y burlador. ${ }^{22}$

así es como Francisco Florit ve al personaje, destacando la soberbia y la vanidad entre sus atributos. Asimismo, también Aurora Egido, al hablar del rechazo de Dios que encarna don Juan, nos dice de él que

19 C. Marlowe, op. cit., p. 54.

20 C. Marlowe, op. cit., p. 59.

${ }^{21}$ T. Molina, El burlador de Sevilla, Madrid, Debolsillo, 2003, p. 28.

22 A. Egido, «Sobre la demonología de los burladores (de Tirso a Zorrilla)», Cuadernos de Teatro clásico, 2, 1988, p.37. 
al margen de la mentira y el perjurio, o del crimen y la lujuria que caracterizan sus obras, don Juan encarna fundamentalmente la práctica del soberbio que aspira a convertirse en dios, único juez y señor de su vida. ${ }^{23}$

Uno de los principales rasgos de este don Juan es la soberbia, puesto que no respeta ni las órdenes de su padre y de su tío, ni las del rey, ni las de Dios. Don Juan desobedece a todos los que le rodean porque cree en su impunidad para realizar cualquier acto contra los órdenes sociales establecidos y se aprovecha de ella.

Esta actitud de soberbia aparece fundamentalmente en la obra con el leitmotiv con el que responde don Juan cada vez que alguien intenta avisarle de los castigos que conllevan sus actos. Revisemos estas intervenciones donde aparece el «iQué largo me lo fiáis!» o alguna de sus variantes: don Juan responde así al aviso que le hace Catalinón en el primer acto cuando le dice que quien trata así a las mujeres lo paga en la muerte; don Juan no respeta la muerte que considera lejana para él. ${ }^{24}$ En el mismo acto, cuando Tisbea advierte a don Juan de la existencia de Dios y de la muerte, éste vuelve a repetir en un aparte su frase, en la que revela su orgullo y soberbia menospreciando el poder superior. En el acto II es su padre, don Diego, el encargado de avisar a don Juan del peligro al que le conduce la actitud despreocupada que tiene. En este caso, el aviso tiene más fuerza y es más vehemente, como podemos observar:

Traidor, Dios te dé el castigo/ que pide delito igual./ Mira que, aunque al parecer/ Dios te consiente y aguarda,/ su castigo no se tarda,/ y que castigo ha de haber/ para los que profanáis/ su nombre; que es juez fuerte/ Dios en la muerte. ${ }^{25}$

La respuesta de don Juan está cargada de soberbia, pues responde afirmando

¿En la muerte?/ ¿Tan largo me lo fiáis?/ De aquí allá hay gran jornada. ${ }^{26}$

lo que demuestra que don Juan se siente joven y lejos de la vejez y la muerte. En esto se muestra exactamente igual que el personaje de Fausto: ambos sólo piensan en el momento presente, creyendo que el futuro no ha de llegar, es decir, optan por el presente y el mundo terrenal, rechazando el futuro y el mundo eterno.

En el acto tercero lógicamente los avisos de los personajes ante la actitud despreocupada de don Juan van creciendo, ya que están dispuestos en ascensión

\footnotetext{
23 Ibidem, p. 90. v. 905.

24 Ibidem, p. 115, vv. 1436-1444.

25 Ibidem, p. 115, vv. 1444-1446.

26 Ibidem, p. 140, vv. 1978-1979.
} 


\section{Elena Nicolás Cantabella}

dramática en la obra. El primer aviso en este acto es el de Catalinón, que cada vez es más concreto con lo que va a pasar. En este caso, advierte a don Juan del «imperio» que hay tras la muerte, esto es, el juicio de Dios y el cielo y el infierno. Don Juan, como siempre, permanece inalterable ante estas advertencias y lanza otra vez su leitmotiv:

Si tan largo me lo fías,/ vengan engaños. ${ }^{27}$

Para don Juan, si el castigo no pertenece a este mundo, no le da miedo, porque sólo mide las consecuencias a corto plazo. En este sentido se muestra como Fausto, ya que a ambos personajes se les ofrecen durante toda la obra avisos para que cambien su actitud y no sean castigados, pero, aunque con diferencias que después comentaremos, los dos rechazan estos avisos, siendo los únicos culpables de su castigo final.

Como hemos afirmado, el leitmotiv resuena constantemente en la obra, sobre todo durante el tercer acto. En él lo encontramos, con variantes, no sólo en boca de don Juan, sino en la de los músicos, con lo que se insiste en la intención didáctica de la obra y en el motivo del castigo del protagonista:

Si de mi amor aguardáis,/ señora, de aquesta suerte,/ el galardón en la muerte,/ ¡qué largo me lo fiáis! ${ }^{28}$

También se repite esta estrofa introduciendo estos versos que destacan la actitud de don Juan de creer que tiene toda la vida por delante:

Si ese plazo me convida/ para que gozaros pueda,/ pues larga vida me queda,/ dejad que pase la vida. ${ }^{29}$

Ante este motivo que representa la actitud vital de don Juan, en el acto tercero, los músicos van a ofrecer su respuesta, en la que se encierra la moral de la obra:

Adviertan los que de Dios/ juzgan los castigos grandes,/ que no hay plazo que no se llegue/ ni deuda que no se pague. ${ }^{30}$

Los dos último versos marcan la intención didáctica de la obra y aparecen como un leitmotiv que se contrapone al «iTan largo me lo fiáis!» que ha aparecido hasta

\footnotetext{
27 Ibidem, p. 140, vv. 1978-1979.

28 Ibidem, p. 160, vv. 2378-2381.

29 Ibidem, p. 161, vv. 2390-2393.

30 Ibidem, p. 177, vv. 2730-2733.
} 
ahora. En la siguiente intervención de los músicos volvemos a encontrar la idea de la fugacidad de la vida terrenal frente a la vida eterna:

Mientras en el mundo vida,/ no es justo que diga nadie/ ¡qué largo me lo fiáis!,/ siendo tan breve el cobrarse. ${ }^{31}$

Asimismo, frente al leitmotiv de don Juan, surge el de don Gonzalo de Ulloa, en el que se observa la justicia divina que castigará todos los pecados de insolencia y soberbia de don Juan; todo ello resumido en la máxima

quien tal hace, que tal pague. ${ }^{32}$

Además de la soberbia, y muy unida a ella, encontramos en el personaje de don Juan una muy acusada vanidad, que va unida a uno de los dos tópicos de la obra: el de burlador. A diferencia del arquetipo que del personaje ofrecen los románticos, el don Juan tradicional no es un seductor, sino un burlador, que consigue mediante engaños el goce de las mujeres, ya que para él lo importante no es el acto sexual en sí, sino el burlar a las mujeres. Así nos dice Francisco Florit en su edición de la obra de Tirso que don Juan es

un burlador, un personaje que hace de la mentira y el engaño su ideario vital. En modo alguno vale calificarlo de seductor o de amante cortés, ya que ese es un perfil esbozado por las versiones románticas que nada casan con la verdadera identidad del Tenorio tirsiano. ${ }^{33}$

Don Juan reconoce abiertamente su condición de burlador, de la que, además, se siente orgulloso, puesto que no busca el placer sexual tanto como la fama, el renombre.

Este orgullo ante su condición de burlador ya aparece al inicio de la obra en una conversación que don Juan mantiene con Catalinón, en la que afirma

Si burlar/ es hábito antiguo mío,/ ¿qué me preguntas, sabiendo/ mi condición? ${ }^{34}$

Pero, si ya aquí don Juan se enorgullece de ser un burlador, en el siguiente fragmento vemos mucho más claro el móvil que mueve a don Juan en sus actos: la fama, como cuando afirma:

\footnotetext{
31 Ibidem, p. 177, vv. 2738-2741.

32 Ibidem, p. 178, v. 2759.

33 Ibidem, prólogo de F. Florit Durán, p. 28.

34 Ibidem, p. 89, vv. 892-895.
} 
Sevilla me llama/ el "Burlador", y el mayor/ gusto que en mí puede haber/ es burlar a una mujer/ y dejarla sin honor. ${ }^{35}$

Esta actitud soberbia y vanidosa, que no respeta ninguna de las normas establecidas, llega a su punto más alto con el espectro de don Gonzalo de Ulloa, puesto que es la soberbia lo que impide ver a don Juan que sobre él se está cerniendo un terrible destino final. Es él mismo el que se introduce en la trampa cuando, creyendo estar fuera del alcance del castigo, le dice a Aminta que si le miente, que un hombre muerto venga a ajusticiarlo:

Si acaso/ la palabra y la fe mía/ te faltare, ruego a Dios/ que a traición y alevosía,/ me dé muerte un hombre... (muerto;/ que vivo, Dios no lo permita). ${ }^{36}$

Asimismo, es él el que, creyendo que como hasta ahora sus actos iban a permanecer impunes, llega a mofarse de un muerto, introduciendo aquí el tópico del convidado de piedra. Don Juan está desafiando ahora no a las normas sociales, sino a las leyes divinas. Pero ni la presencia en su casa del espectro del comendador va a conseguir rebajar la soberbia de este personaje. A diferencia del galán del romance medieval, don Juan no siente miedo, todo lo contrario, es fanfarrón casi hasta el momento antes de su muerte, como lo comprobamos en sus intervenciones cuando se encuentra con don Gonzalo en la iglesia:

Y si te importa/ levantaré estos pilares [...] Tengo brío,/ y corazón en las carnes. ${ }^{37}$

Como hemos visto, aunque existen diferencias en el tratamiento de ambos personajes que ya comentaremos más adelante, tanto Fausto como don Juan tienen como rasgo común la soberbia y la vanidad, lo que les conduce a su castigo divino.

Otra de las características comunes a ambos personajes, y que tiene que ver con la época en la que aparecen, es el desafío de las normas establecidas.

En el caso de Fausto debemos señalar que esta ruptura con las normas se relaciona con el Renacimiento, con el cambio de mentalidad que se opera en él. El hombre se convierte en centro del universo y ya no se siente sometido a Dios. Además, la vida se contempla como algo digno de ser vivido y aparece el ansia de los hombres por la búsqueda de su felicidad. El mundo terrenal se presenta ahora, no como el valle de lágrimas o el camino hacia el otro, el celestial, sino autónomo. Y surge la vida de la

\footnotetext{
35 Ibidem, pp. 109-110, vv. 1309-1313.

36 Ibidem, p. 145, vv. 2073-2078.

37 Ibidem, p. 175, vv. 2704-2705, 2705-2706.
} 
fama, ya que los hombres tienen la necesidad de dominar alguna disciplina, como le sucede a Fausto. Toda esta ideología renacentista lleva al hombre a intentar superar los límites, aunque ello suponga pagar el más alto precio imaginable.

Fausto es un personaje precursor del individualismo, ya que se trata de un hombre libre (aunque su libertad supone una gran contradicción), y recuperado, que se asienta sólo sobre sus pies y no sobre la tabla de la fe, a la que no necesita, aunque no puede rechazarla totalmente, lo que le produce grandes remordimientos.

Como afirma Martínez López, los hechos que manifiestan en el mundo una nueva conciencia, esto es: los avances científicos, el nacimiento del racionalismo, el descubrimiento del nuevo mundo, que despierta en el hombre un deseo de explorar nuevos territorios, no sólo físicos, sino también espirituales, provocan lo siguiente:

entre los temas y convenciones del Renacimiento, la negación del concepto de límite es una de las ideas que más consecuencias traerán, en todos los órdenes de la existencia, en especial en el político, el económico y el literario. Como sugiere $\mathrm{H}$. Haydn, la negación de la idea de límite hunde sus raíces en la vanidad del saber, parte de la negación de la existencia de leyes universales, y llega, como Fausto, a un total rechazo del concepto de frontera intelectual que finalmente acaba, en muchos casos, en la magia y el satanismo. ${ }^{38}$

Como ya hemos comentado a la hora de señalar la soberbia de Fausto, el personaje no se detiene ante ningún límite: si las ciencias que ha estudiado hasta el momento no le satisfacen, no duda en entregarse a las artes ocultas, con todo lo que ello conlleva, para satisfacer su necesidad de alcanzar el conocimiento al que aspira.

En la obra observamos los lazos que unen la necesidad de conocimiento y poder de Fausto con la necesidad de conocimiento y de poder que sienten sus contemporáneos tras haber conquistado territorios lejanos, como podemos ver en la siguiente intervención de Valdés, en su diálogo con Fausto, en la que declara su ambición por ser como los colonizadores españoles:

Estos libros, Fausto, vuestro ingenio/ y nuestra experiencia harán/ que todas las naciones nos veneren./ Al igual que los indígenas de las Indias/ obedecen a sus amos españoles,/ así los espíritus de todos los elementos/ estarán siempre a nuestro servicio [...] De Venecia han de traernos bajeles repletos,/ y de América el vellocino de oro que todos los años/ llena las arcas del viejo rey Felipe./ Si el sabio Fausto se muestra resuelto. ${ }^{39}$

38 M. Martínez López, op, cit., p. 169.

${ }^{39}$ C. Marlowe, op, cit., p. 57. 
Son, pues, los acontecimientos históricos, y el posterior cambio en la mentalidad de la época, los que provocan el desmedido afán de Fausto por conocer y dominar, superando los límites que hasta ahora nadie había desafiado.

Este afán por descubrir el mundo entero y conocer los auténticos límites del mundo, que muestra una búsqueda propia de la época, también aparece por medio del coro cuando éste nos informa de que Fausto está sobrevolando el mundo para conocer su geografía, como podemos comprobar en el siguiente fragmento:

Nuevas empresas le reclaman/ y, a lomos ahora de un dragón/ que corta el aire leve con sus alas,/ ha partido a verificar la cosmografía/ que mide las costas y los reinos de la tierra. ${ }^{40}$

$\mathrm{Al}$ inicio de la obra, Fausto se nos muestra como un hombre de su tiempo, como un humanista, que ha buscado el conocimiento en todas las disciplinas, que ha llegado al límite de todas ellas, pero que no ha conseguido calmar su ansia de sabiduría. Ha buscado en la Lógica, en la Filosofía, en la Medicina, en el Derecho, hasta en la Teología, en todas las disciplinas que son necesarias para formar a un perfecto humanista, pero de todas se ha cansado, porque ninguna le ofrece lo que ansía, hasta que aparece la magia. Esta superación del límite de estas disciplinas podemos observarla en la siguiente intervención de Fausto:

Define tus intereses, Fausto, y empieza/ a comprobar la hondura de lo que has de profesar./ Iniciada ya esa senda, aparenta ante el mundo/ ser un hombre de religión,/ pero aspira al límite de todas las artes/ y vive y muere en las obras de Aristóteles. ${ }^{41}$

También se establece una relación entre Fausto y el humanismo por medio de la universidad en la que el coro nos dice que ha estudiado el personaje, la universidad de Wittenberg. Esta universidad se convirtió desde su fundación en 1502 en sede de una gran corriente de pensamiento caracterizada por la Reforma, ya que en ella estudia Lutero y es en ella donde clava sus noventa y cinco tesis contra la venta de indulgencias. Esta universidad representa, pues, un hervidero de nuevas corrientes ideológicas y teológicas que son un rechazo de las ideas anteriores y una revolución. No es extraño que Marlowe elija un centro de estudios de donde surgen voces disconformes con las ideas hasta ahora establecidas.

Estas ideas de la época son las que llevan a Fausto a intentar superar los límites y a equiparase con Dios, lo que le conduce al castigo final, en el que reniega de sus

\footnotetext{
40 Ibidem, p. 99.

${ }^{41}$ Ibidem, p. 52.
} 
conocimientos y de sus ansias de poder y dominio, rechazando ahora sus libros y la propia universidad en la que ha estudiado:

Aunque mi corazón se alegra y estremece al recordar que aquí han transcurrido en el estudio treinta años de mi vida, ahora quisiera no haber visto nunca Wittenberg, nunca haber leído un solo libro. ${ }^{42}$

El caso de don Juan, por su parte, es distinto, pero comparte con Fausto su desafío a las normas. Don Juan presenta un proceso gradual de desafío de carácter creciente. En primer lugar nos encontramos con la ruptura de las normas reales, ya que engaña a Isabela en el palacio del propio rey de Nápoles, una ruptura que vuelve a aparecer, pues incumple la orden de destierro que el rey don Alfonso le ha dado.

Pero no sólo incumple reglas relativas a los dictados de los reyes, sino que también incumple normas de tipo moral al engañar a un amigo, por lo que no respeta ni los códigos de lealtad que el marqués de la Mota sí que parece respetar. Asimismo, también se opone a este personaje, ya que, mientras que la Mota establece el límite de sus ofensas a burlar a unas prostitutas, don Juan burla a mujeres de todas las clases sociales, como son Isabela y doña Ana.

Yendo más lejos todavía, don Juan incumple las normas sociales cuando finge dar palabra de matrimonio a Aminta, ya que ésta es una mujer de una clase social baja y, según las normas de la época, no puede casarse con un noble.

Pero las leyes que van a conducirlo a su castigo son las leyes divinas, que, como hemos visto anteriormente, vulnera con impunidad aunque los demás personajes le advierten constantemente de ellas. El mayor delito de don Juan es el de matar a don Gonzalo y luego burlarse de su estatua, ya que no está burlándose de un hombre, sino de una sombra, de un espectro del otro mundo. Está despreciando la paz de los muertos y, con ella, el reino de Dios. Es aquí donde la actitud de don Juan muestra su mayor insolencia y su mayor agravio y desafío.

Por lo tanto, aunque tratados con diversos matices, los comportamientos tanto de Fausto como de don Juan muestran un desafío contra las normas, reglas y leyes que no pueden ser vulneradas sin un castigo terrible.

Estas actitudes insolentes, soberbias y orgullosas de ambos personajes conectan con la siguiente característica que los dos comparten: la actitud hedonista ante la vida que surge como respuesta de la época al temor hacia la muerte. Según Martínez López,

$\overline{42}$ Ibidem, p. 171. 
es la angustia por el paso del tiempo y la concepción de la muerte como una fractura lo que provoca actitudes epicúreas en el personaje de Fausto. ${ }^{43}$

Recordemos que nos encontramos en una época marcada por los constantes conflictos provocados por los enfrentamientos religiosos, como son las guerras de religión y las masacres por las mismas causas, por ejemplo la denominada "Noche de San Bartolomé" en Francia. Los enfrentamientos y las crisis religiosas provocan un estado de angustia, porque, además, el comenzar a cuestionarse la figura de Dios produce una angustia en el hombre que quiere libertad, pero que no encuentra sosiego, como le sucede a Fausto. Esta fractura de la muerte es afrontada por este personaje mediante una actitud de exaltación de los placeres, como podemos comprobar en esta intervención:

¡Bien atiendes a mis deseos, Mefistófeles!/ Mientras siga en la tierra deja que me sacie/ de todo lo que alegra el corazón humano./ Agotaré mis veinticuatro años de libertad/ en placeres y frivolidades./ ¡Que admiren el nombre de Fausto los confines de la tierra/ mientras perdure su hermosa estampa! ${ }^{44}$

Aunque Fausto tiene, a diferencia del personaje de don Juan, momentos de remordimiento, ya que él sí que es consciente en muchos momentos de que su conducta le va a precipitar hacia el infierno, su resolución final siempre es la de apurar el hoy y despreciar el mañana. Hasta cuando siente que el plazo está próximo a expirar, porque Fausto sí que conoce cuál es la fecha de vencimiento de su contrato a diferencia de don Juan, se asusta, pero continúa su actitud despreocupada, como observamos cuando dice

¿Qué eres Fausto, sino un hombre condenado a morir?/ La fecha fatal se está acercando a su término;/ la desesperación tiñe de recelo mis pensamientos./ Olvidaré estos pesares con un sueño reparador./ ¡Bah, Cristo perdonó al ladrón en la Cruz!/ Así que, Fausto, descansa tranquilo. ${ }^{45}$

Pero si en algún momento se nos muestra la actitud despreocupada de Fausto ante la muerte es cuando su criado Wagner nos habla de ella, como podemos observar en su siguiente intervención:

Creo que mi señor siente cerca la muerte,/ porque me ha dejado todos sus bienes./ Con todo, si su fin estuviera próximo,/ no andaría en comilonas, jaranas y borracheras/ con estudiantes, como hace ahora,/ que está cenando con tragones

\footnotetext{
43 M. Martínez López, op. cit., p. 94.

44 C. Marlowe, op. cit., p. 102.

45 Ibidem, p. 144.
} 
tales/ como yo no había visto en toda mi vida./ ¡Vaya aquí vienen! Parece que termina la fiesta. ${ }^{46}$

Wagner no entiende cómo su amo se decanta por una vida volcada hacia los placeres físicos, en vez de mostrarse preocupado por su pronta muerte, intentando ganar la gracia divina. Ya veremos posteriormente cómo Fausto no puede ganar esa gracia divina por su propia personalidad.

Al final de la obra se insiste sobre la actitud hedonista del protagonista que, ante las advertencias del enigmático personaje del "Anciano", decide ordenarle a Mefistófeles que le conceda a la mujer más hermosa de la antigüedad, a Helena de Troya. Incluso, cuando a Fausto sólo le queda una hora hasta su final, no quiere poner en paz su alma, sino que, sabiéndose ya condenado de antemano, lo único que pretende es que esa hora sea más larga, que se eternice:

¡No te resta sino una única hora de vida,/ para después acabar eternamente condenado!/ ¡Deteneos, errátiles esferas del cielo/ para que el tiempo cese/ y nunca llegue la media noche! ${ }^{47}$

para poder pedir una redención que podría haber pedido ya.

En cuanto a don Juan, su caso es especial, ya que el momento histórico que está viviendo España cuando Tirso redacta la obra es el comienzo del declive del Imperio. Una política exterior desastrosa, la corrupción de la corte, el continuo desgaste que suponen las guerras de religión, la peste de finales del siglo XVI, la profunda crisis moral... todo ello produce dos actitudes diferentes ante la negativa imagen de la vida: por un lado, la de aquellos que satirizan la realidad, que critican lo que está sucediendo y muestran una actitud de rechazo del mundo y, por otro, la de aquellos que se lanzan en busca de los placeres, mostrando actitudes hedonistas.

Don Juan es la imagen del hedonista que está al margen de todo aquello que no sea el yo, el aquí y el ahora. Quiere disfrutar de todo lo que le se le ofrece rechazando así la posible redención, pues observa el castigo tan lejano, que él cree que no puede alcanzarle. La seña de su actitud hedonista es ese « para don Juan el único momento que importa es el presente.

Si las actitudes de exaltación de los placeres están claras en los dos personajes, resulta más arriesgado afirmar que ambos representan una rebelión ante Dios, ya

\footnotetext{
$46 \quad$ Ibidem. P. 161.

47 Ibidem, p. 175.
} 
que, si en el caso de Fausto ésta es más evidente, en el de don Juan hay opiniones enfrentadas.

Sería fácil recurrir a la biografía de Marlowe para definir al personaje de Fausto, ya que los datos que tenemos sobre el dramaturgo nos hablan de un hombre misterioso, interesado por alcanzar un conocimiento superior, ateo, blasfemo, pendenciero... como aseguran las acusaciones que sobre él vertieron Thomas Beard, Simon Aldrich, Francis Meres, Richard Baines, o el propio Thomas Kyd. Pero no debemos caer en la falsa identificación Marlowe - Fausto, ya que lo que representa el personaje es la rebelión que lleva a cabo el hombre renacentista al enfrentarse a Dios, trasladando el eje del universo desde la divinidad hasta el hombre, y no la de un solo hombre.

La opción de Fausto, que elige el placer y la soberbia, conlleva la rebelión ante el reino de Dios y, consecuentemente, la condenación. Fausto se rebela porque opta por la vida terrenal, por lo que se decanta por el cuerpo, el tiempo y el mundo, como ya hemos comentado antes. Liberándose de la fe debe sostenerse sólo sobre sus propios pies, lo que, como veremos, no es nada fácil, y además debe superar los límites condenándose a pagar el precio más alto que podría imaginar.

Como hemos mencionado, el delito de Fausto es el de pretender alcanzar un conocimiento que al hombre le ha estado vedado, esto es, se muestra como Adán y Eva que comen del fruto prohibido puesto que quieren ser como Dios, o como el propio Lucifer, que deja de seguir los dictados divinos, contradiciendo una orden de Dios. Lucifer, como el hombre renacentista, comienza a cuestionar verdades que hasta entonces habían sido inviolables.

El delito de Fausto es el de la blasfemia por querer equipararse a Dios, puesto que no le vale sólo el poder de los reyes, sino que quiere conseguir un poder superior, porque un mago es un dios poderoso. Para poder llegar a estos deseos el personaje debe recurrir a unos planteamientos erróneos sobre el pecado, como podemos comprobar en el siguiente fragmento:

¿Es la muerte la recompensa del pecado? ¡Qué penoso! Si pecasse negamos, fallimur, et nulla est in nobis veritas. Y si decimos que no pecamos, nos engañamos a nosotros mismos y la verdad no mora en nosotros. ¡Vaya!, pues tal vez tengamos que pecar $\mathrm{y}$, en consecuencia, morir. ${ }^{48}$

Fausto da una interpretación distinta al pecado que la tradicional, esto es, piensa por sí mismo, cuestiona los dogmas y los reinterpreta a su manera. Ésta es una manera de rebelarse ante Dios y ante la religión.

48 Ibidem, p. 53. 
La actitud rebelde y desafiante de Fausto no se queda aquí, sino que, al inicio de la obra, en su diálogo con Mefistófeles, dice que no cree en el infierno y en el cielo $\mathrm{y}$, aunque no va a mantener esta actitud durante toda la obra, esta negación es una blasfemia, una provocación y un acto de enorme rebeldía. Podemos comprobarlo en sus palabras:

No me aterran palabras de condenación,/ pues no distingo entre el Averno y el Elíseo. $^{49}$

También debemos destacar que Fausto no emplea la palabra «cielo», ni «paraíso», de índole cristiana, sino las palabras «averno»y, sobre todo, «Elíseo», referentes a ámbitos paganos.

Frente a esta actitud, es realmente sorprendente la adoptada por el demonio Mefistófeles, que habla del castigo de aquellos ángeles que osaron levantarse contra Dios

Espíritus desventurados que con Lucifer caímos,/ que con Lucifer conspiramos contra Dios/ y con Lucifer por siempre estamos condenados. ${ }^{50}$

y que se lamenta por la falta de libertad que tiene como consecuencia de haberle dado la espalda a Dios. Mefistófeles dice encontrarse en el infierno, pues éste está en todas partes, lo cual es un concepto bastante moderno. Así, en sus palabras:

No, no estoy fuera de él, esto es el infierno./ ¿Crees tú que yo, que vi el rostro de Dios/ y supe de los gozos eternos del cielo,/ no me veo atormentado por mil infiernos/ al sentirme privado de la dicha imperecedera?/ ¡Oh, Fausto!, deja ya estas preguntas frívolas/ que intimidan mi espíritu desfallecido. ${ }^{51}$

muestra su arrepentimiento e intenta que Fausto no siga su ejemplo, algo que no va a conseguir.

Porque Fausto prefiere alcanzar el conocimiento y, como permanecer fiel a Dios significa aceptar los límites que la religión impone, opta por la magia. Y para alcanzar esta magia recurre a un pacto con el demonio, cayendo en la trampa de querer verse liberado de Dios para terminar bajo el dominio de Satanás. Fausto firma un pacto con el Diablo cuyas cláusulas incluyen: vivir los placeres, tener como siervo a Mefistófeles que debe concederle todo aquello que él pida o contestar a todo lo que le pregunte,

\footnotetext{
49 Ibidem, p. 65.

50 Ibidem, p. 66.

51 Ibidem, p. 66.
} 
ayudar a sus amigos y asesinar a sus enemigos, y permanecer fiel a su voluntad, todo ello por un plazo de veinticuatro años; a cambio de ello, Fausto le rendirá su alma.

Pero pronto se revela la duda en Fausto, que según Martínez López adquiere la apariencia de una psicomaquia, esto es, una «batalla entre virtudes y vicios dentro del alma humana ${ }^{52}$ que conduce a Fausto a un movimiento pendular del bien al mal. Esta lucha interior o conflicto que se desarrolla en el alma de Fausto podemos apreciarla en muchos momentos de la obra, como, por ejemplo cuando se debate al decir

Por fuerza, Fausto, has de condenarte ahora./ Ya no puedes salvarte./ ¿De qué sirve, entonces, pensar en Dios o en el cielo?/ Aparta esas vanas fantasías y desespera.../ ¡desespera de Dios y confía en Belcebú!/ No retrocedas ahora. ¡Ánimo Fausto!/ ¿Por qué esos titubeos? ¡Oh, algo me resuena en los oídos!/ «Abjura de esta magia, vuelve a Dios de nuevo».53

Pero, aunque en muchos momentos Fausto duda de su decisión, siempre es más fuerte en él su constancia en el mal que su inclinación al bien, como podemos volver a observar momentos después de que haya dudado, cuando insiste en no creer en la otra vida ni en el castigo divino: «Yo creo que el infierno es pura fábula», y un poco más adelante:

¿Piensas acaso/ que Fausto es tan tonto que cree/ en el sufrimiento después de esta vida?/ No, esas son monsergas y cuentos de vieja. ${ }^{54}$

Esta actitud de descreimiento contrasta con la insistencia de Mefistófeles en demostrar que cielo e infierno son reales.

Pero el movimiento del que hablamos va a estar presente durante toda la obra, y Fausto va a volver a tener constantes momentos de arrepentimiento. Ejemplos de ello son:

Cuando contemplo los cielos, me arrepiento/ y te maldigo, perverso Mefistófeles,/ por haberme privado de esos goces..$^{55}$

Por supuesto el único culpable de la condenación de Fausto es el propio Fausto, puesto que Mefistófeles sólo es el siervo de éste, además de intentar avisarle de los

\footnotetext{
52 M. Marlowe, op. cit., p. 73.

53 Ibidem, p. 81.

$54 \quad$ Ibidem, p. 83.

55 Ibidem, p. 89.
} 
resultados de sus actos, a diferencia del Mefistófeles de Goethe que se muestra como un manipulador maligno, que juega con el alma de Fausto.

¡Oh, Cristo Salvador, Salvador mío,/ ayúdame a salvar el alma acongojada de Fausto! ${ }^{56}$

Cuando más adelante va llegando el momento en el que expira el pacto, va a cobrar más importancia el conflicto en el que se debate. Fausto empieza a preocuparse, como sucede ante el personaje del Anciano, ante el que pronuncia:

¿Dónde estás, Fausto? ¿Qué has hecho, desgraciado?/ ¡Estás condenado, Fausto, condenado! ¡Desespera y muere ${ }^{57}$

Pero, ¿por qué, si Fausto tiene miedo y duda, no consigue arrepentirse y alcanzar la gracia de Dios? Pues por lo que nos revela en su siguiente intervención:

Execrable Fausto, ¿dónde está ahora la clemencia?/ Sí, me arrepiento. Y aún así desespero./ Infierno y gracia forcejean en mi pecho por el triunfo./ ¿Qué he de hacer para eludir los lazos de la muerte? ${ }^{58}$

Porque Fausto, como asegura Martínez López, no puede creer en la Misericordia divina y ello supone un acto de orgullo que anula totalmente su arrepentimiento. ${ }^{59} \mathrm{De}$ ahí que, mientras que personajes como Irene de Las cadenas del demonio o Cipriano de El mágico prodigioso, ambas de Calderón, o Don Gil de El esclavo del demonio de Mira de Amescua, consiguen salvarse porque, a pesar de haberse apartado de Dios, finalmente vuelven a él, Fausto no puede regresar a Dios porque en el fondo no puede confiar en él.

En este sentido, si queremos encontrar un personaje de un drama teológico del teatro español del XVII que se asemeje más a Fausto en este aspecto, podemos señalar a Paulo, de El condenado por desconfiado de Tirso de Molina, que muestra el mismo desencanto ante Dios y ante la religión al darse cuenta de que todo lo que ha hecho no le sirve de nada y que corre la misma suerte que un bribón llamado Enrico.

Ahora bien, si en Fausto es incuestionable su rebelión, más difícil es mostrarla en don Juan. Mientras que Américo Castro «subraya el «aspecto trágico del burlador,

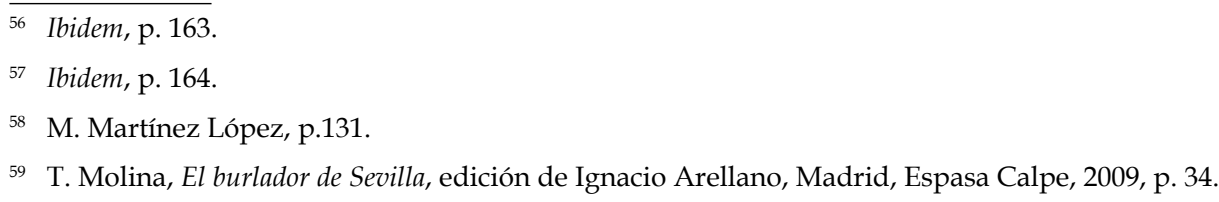




\section{Elena Nicolás Cantabella}

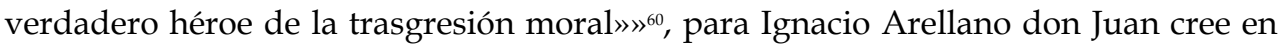
Dios simplemente porque se trata de un personaje de la comedia española del XVII y esto es una convención. Don Juan, prosigue Arellano, no posee una condición de creyente operativa, esto es, «no se opone a Dios: Dios le es indiferente». ${ }^{61}$ Podemos confiar en el buen criterio de Arellano apoyándonos en el ejemplo que propone: cuando don Juan se burla de la estatua y continúa con su actitud insolente, seguramente actúa así, no porque quiera rebelarse contra Dios, sino porque no quiere que nadie piense que es un cobarde, es decir, simplemente por su soberbia, su orgullo y su vanidad.

Un argumento que apoya esta tesis lo podemos encontrar al confrontar las dos obras. Si Fausto tiene miedo y se arrepiente constantemente de sus actos es porque cree en Dios, pero no confía en él, pero en don Juan no hay nunca miedo, ni arrepentimiento, porque don Juan actúa al margen de Dios. Si se rebelase contra él, tendría que creer en él y esta creencia debería aparecer de alguna manera.

Otra confrontación nos puede ayudar también. Frente a El burlador de Sevilla, en la otra obra tirsiana, El condenado por desconfiado, sí que hay una explícita rebelión ante Dios, porque el personaje de Paulo va desde la creencia hasta la rebelión. No debemos olvidar que para rebelarse debe haber un motivo oculto contra Dios. Desobedecer a Dios, que es lo que hace don Juan, no es lo mismo que rebelarse contra él, que es lo que hacen Fausto y Paulo.

Lo que, por otro lado, no podemos poner en duda es que don Juan, como Fausto, es un agente del caos, al servicio de la subversión, como nos dice Ignacio Arellano:

Sin duda el burlador reclama para sí la condenación. Rebelde consciente y heroico (como creen algunos estudiosos) o simple malvado sin más objetivos que cumplir sus objetivos (como a mí me parece), don Juan es agente del mal y del caos. ${ }^{62}$

Don Juan siembra el caos allá donde va. En Nápoles no sólo goza de Isabela despojándola de su honor, sino que sus actos conllevan la condena del duque Octavio, que debe huir a España. En el pueblo de Tarragona burla a Tisbea, al tiempo que frustra las intenciones amorosas de su amado Anfriso. Ya en Sevilla, donde sus actos son más terribles, engaña a su amigo el Marqués de la Mota, intenta burlar a doña Ana, asesina a don Gonzalo el padre de ésta y, además, sus actos tienen como consecuencia que de la Mota sea condenado a muerte como autor del asesinato. Finalmente, en el pueblo de Dos Hermanas, rompe los lazos matrimoniales de Batricio y de Aminta sembrando la

\footnotetext{
60 Ibidem, p. 35.

${ }^{61} \quad$ Ibidem, p. 37.

62 A. Egido, op. cit., pp. 37-54.
} 
ambición en ésta y en su padre, aunque ambos no son precisamente víctimas inocentes. Sólo tras la muerte del protagonista se restablece un cierto equilibrio, aunque éste ha sido totalmente dañado y sus consecuencias son irreversibles.

Por tanto, aunque don Juan no actúe de manera deliberada contra Dios, se trata de un personaje que se acerca bastante a lo demoníaco por sus actos, como nos asegura Aurora Egido:

une la hazaña sexual (la burla y la posesión repetida de mujeres; el engaño de los hombres, padres, prometidos, que las defienden o aman), el sadismo y el cinismo con que desempeña su irrefrenable - esencia semántica de "burlar" -; la convicción maligna y el valor inusitado que le confiere su total indiferencia hacia las leyes sociales o divinas; su ciega competitividad en el mal, que raya en lo demoníaco, su apetito irrefrenable. ${ }^{63}$

Igual que don Juan siembra el caos allá donde va, Fausto también actúa como un agente al servicio de la subversión y del caos en el orden imperante, aunque en sus actuaciones la magia juega un papel muy importante y el humor reina en estas escenas, lo que lo separa de don Juan. Fausto, por ejemplo, se disfraza para poder salvar a Bruno, un hereje que el Papa quiere ajusticiar, o siembra el caos, episodio bastante ridículo para los poderes que se prometía el personaje al inicio de la obra, al hacer desaparecer alimentos o golpear a miembros de la alta jerarquía de la Iglesia católica gracias su invisibilidad, o en el episodio todavía más burlesco y cómico en el que Fausto y Mefistófeles reparten golpes a unos frailes.

Lo cierto es que don Juan sin utilizar la magia causa mucho más daño que Fausto, que se limita a un par de episodios más propios de un bufón que de un auténtico mago protegido por el propio Lucifer.

Otro de los elementos que unen a los personajes de Fausto y de don Juan es su mismo final. Ambos son castigados por elegir el placer terrenal antes que la salvación. Para confrontar las semejanzas de los dos tomando como base su mismo delito y castigo, merece la pena confrontar lo que sobre don Juan nos dice Aurora Egido con lo que nos dice Miguel Martínez López sobre Fausto. La primera nos dice respecto a don Juan que «Tirso concibió a su personaje con los rasgos del rebelde que al alzarse contra la norma, se destruye» ${ }^{64}$, mientras que Martínez López dice algo muy similar de Fausto: «el Doctor Fausto, que sellando un pacto con el diablo, encarnó el drama de la naturaleza caída y la trágica inevitabilidad del infierno» ${ }^{65}$.

\footnotetext{
${ }_{63}$ A. Egido, op. cit., pp. 54.

${ }_{64}$ M. Martínez López, op. cit., p. 13.

65 M. Marlowe, p. 173.
} 
En cuanto a Fausto, su condena es irremisible, ya que resultaría del todo imposible que tras sus dudas no fuera condenado. Fausto no puede arrepentirse y creer en la Misericordia divina, por lo que debe ser castigado; lo contrario resultaría escandaloso.

El motivo del castigo de este personaje nos lo ofrecen los personajes que observan su caída final. Mefistófeles nos dice que quien ríe en la tierra, llora en el infierno, es decir que Fausto es condenado por la elección que realiza y de la que ya hemos hablado. También el Ángel Bueno nos avisa de que Fausto eligió la vida terrena («Pero tú, en verdad, amaste más el mundo») ${ }^{66}$ de la misma manera que el Ángel Malo («Que quien ama el placer perecerá por el placer»). ${ }^{67}$ Pero la auténtica clave del castigo de este personaje, que sirve de aviso para otros que puedan incurrir en su mismo atrevimiento, nos lo da la intervención del coro, que cierra la obra:

Fausto ha partido: ponderad su caída en los infiernos./ Su satánico destino puede que exhorte al prudente/ a apartarse receloso de las cosas prohibidas,/ cuyo misterio tanto induce a los ingenios audaces/ a intentos mayores de los que el cielo permite. ${ }^{6}$

Por su parte, el castigo de don Juan es significativo, ya que es inusual en el teatro barroco español, como señala Francisco Florit, quien tras caracterizar al personaje de don Juan y hablar de su ruptura de las normas, afirma:

Todo ello, ineluctablemente, le llevará a la condenación. Cosa, por cierto, nada frecuente en el teatro español del Siglo de Oro. ${ }^{69}$

Algo para lo que también podemos señalar la salvación de los personajes citados en Las cadenas del demonio, El mágico prodigioso y El esclavo del demonio, de tema faústico, pero también la condena del personaje en El condenado por desconfiado.

Al igual que sucede en la obra de Marlowe, don Juan tiene la posibilidad de cambiar su actitud y de salvarse. Baste recordar el romance medieval del que hemos hablado, en el que el galán se salva al mencionar a Dios. Pero don Juan no lo hace. ¿Por qué ni Fausto ni don Juan son capaces de salvarse a tiempo? En el caso de Fausto hemos visto cómo su desconfianza hacia Dios le impide un arrepentimiento sincero. Por su parte, don Juan no puede arrepentirse porque su tremenda soberbia, su orgullo, lo ciega y no ve lo que está sucediendo, así que, cuando quiere confesarse porque siente

\footnotetext{
66 Ibidem, p. 175 .

67 Ibidem, p. 179.

68 T. Molina, Edición de Francisco Florit, p. 28.

69 T. Molina, p. 179, vv. 2767-2769.
} 
cerca el castigo, ya es demasiado tarde, como observamos en el siguiente fragmento: ante la súplica de don Juan, «Deja que llame/ quien me confiese y absuelva», don Gonzalo responde, «No hay lugar, ya acuerdas tarde». ${ }^{70}$

Como hemos podido comprobar, los personajes de Fausto y de don Juan, en sus versiones primeras, de Marlowe y de Tirso, comparten una serie de elementos que los acercan, aunque no debemos olvidar que hay diferencias entre ambos personajes, como son las distintas motivaciones que los mueven, el conflicto teológico presente en Fausto y ausente en don Juan, la presencia o ausencia de elementos mágicos o demoníacos, etc. Nos encontramos con dos personajes propios de su momento histórico, pero que consiguen traspasar su tiempo y arraigar en cualquier época histórica porque ofrecen un gran poder de atracción sobre el hombre.

\section{ELEMENTOS PRESENTES EN AMBAS OBRAS}

Además de encontrar lazos entre los personajes de Fausto y de don Juan, también hay vínculos entre ambas obras, que vamos a repasar brevemente.

En primer lugar nos encontramos con el contraste entre el tono serio y el tono cómico y burlesco, tan habitual en las obras del siglo XVII y que actúa como un contrapunto. Debemos recordar que el siglo XVII es una época de grandes contrastes.

Una de las características de la obra de Marlowe, según Julio César Santoyo y José Miguel Santamaría, es precisamente esta alternancia de escenas trágicas con escenas grotescas, que ellos vinculan a la tradición medieval presente todavía en la obra. ${ }^{71}$ Esta alternancia podemos verla oponiendo el personaje de Fausto a los personajes de sus criados Wagner y Robín. Mientras que Fausto pacta con el Diablo para poder alcanzar un conocimiento y un poder que ahora se le escapa, Wagner afirma que vendería su alma por una paletilla de cordero («y tan hambriento que estoy seguro que daría el alma por una paletilla de cordero, aunque fuera cruda») ${ }^{72}$ y Robín insiste en la misma burla («Nada de eso, que si la fuese a pagar tan cara, os aseguro que me la haría servir bien tostadita y con mucha salsa»). ${ }^{73}$

Nos encontramos con otra escena grotesca cuando aparece un demonio disfrazado de mujer, que contrasta con el inmediatamente anterior diálogo entre Fausto y Mefistófeles, en el que ambos discutían acerca de la existencia del cielo y del

\footnotetext{
70 C. Marlowe, op. cit., prólogo, pp. 22-25.

71 Ibidem, p. 68.

72 Ibidem, p. 69.

73 Ibidem, pp. 96-98.
} 
infierno. El contraste entre la profundidad de estos argumentos y la presencia de este demonio es enorme, ya que el episodio parece más bien una parodia que otra cosa. ${ }^{74}$

En otra escena vuelven a ser los criados los que parodian los poderes sobrenaturales de su amo Fausto. Robín le dice a Ricardo:

¿El amo conjurarme a mí? ¿Sabes qué te digo? Que si aparece el amo, le planto en la frente el par de cuernos más hermosos que hayas visto en tu vida. ${ }^{75}$

Robín se burla de la magia y del diablo, oponiéndose a su amo, lo que también nos encontramos en la obra de Tirso, como veremos a continuación o en El don Juan de Molière, o en las obras de tema faústico de Calderón.

Otra vez volvemos a encontrarnos con el criado, Robín, como contraposición al personaje de Fausto, utilizando la magia para cosas mundanas y vulgares (protegerse del tabernero que le acusa de haber robado una copa) e invocando al demonio ( «iLa o sola o; Demigorgon, Belcher, Mefistófeles!»). ${ }^{76}$ Asimismo, también tiene tono jocoso el castigo que les impone Mefistófeles a ambos criados por sus insolencias: a Robín lo convierte en perro y a Ricardo en mono. ${ }^{77}$

Ya hemos hablado anteriormente de dos episodios cómicos que tienen como intención la crítica al catolicismo: la primera es el desorden que Fausto crea en el palacio del Papa y el segundo los golpes que propinan éste y Mefistófeles a los frailes.

Frente al humor grotesco más bien propio de la Edad Media, la obra de Tirso de Molina carece de elementos grotescos y su humor y contrastes son más limitados. El humor se reduce a la figura del gracioso, Catalinón, a sus referencias sexuales y escatológicas, y a las referencias sexuales que hacen don Juan y el marqués de la Mota, como el diálogo entre estos dos últimos en el que hablan de las prostitutas o las bromas sobre la deshonra y burla de los personajes que don Juan va a ofender, sin olvidar la broma sobre los cuernos del marqués. Por lo que la obra tiene un carácter más globalmente trágico. No debemos olvidar que en la obra de Marlowe el único personaje que sufre es el protagonista, mientras que en la obra de Tirso todos los personajes sufren percances trágicos.

Otro de los elementos que podemos rastrear y analizar en ambas obras son los elementos propios del mundo infernal.

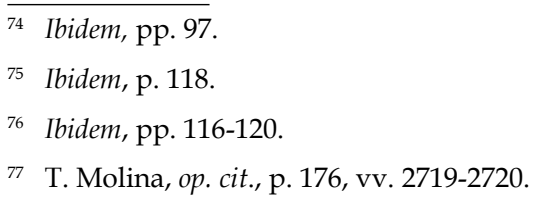


En Fausto estos elementos son una constante, ya que aparecen multitud de demonios, entre ellos Mefistófeles, el propio Lucifer, el Ángel Malo, contrario del Ángel Bueno... desde el comienzo de la obra. Esta presencia de elementos infernales está relacionada también con la presencia de elementos que remiten a las moralidades inglesas medievales, como son los elementos alegóricos de los Siete Pecados Capitales.

Por su parte, en El burlador de Sevilla, los elementos infernales que aparecen se encuentran sobre todo al final de la obra, cuando aparece el espectro de don Gonzalo de Ulloa e invita a don Juan a cenar en la iglesia. Estos elementos son las serpientes que aparecen como manjar en el banquete («Este plato es de alacranes/ y víboras») ${ }^{78}$, que también están presentes en la obra de Marlowe en el castigo de Fausto ( « ¿Víboras y serpientes, dejadme respirar un poco más!») ${ }^{79}$ y que forman parte del tópico que Carmen Hernández Valcárcel denomina “comidas alegóricas”, en este caso vinculadas a la muerte, ya presentes en el Poema de Gilgamesh o en algunas danzas de la muerte medievales $^{80}$, y el fuego, que aparece en el momento en que don Juan es castigado y que, como veremos, tiene una gran simbología en la obra, y que también aparece en la obra de Marlowe cuando el tercer estudiante comenta lo que se veía en la casa de Fausto cuando esté estaba siendo castigado:

y a esa misma hora la casa parecía envuelta en llamas/ por el pávido horror de esas furias infernales. ${ }^{81}$

Otros elementos infernales que también aparecen en la obra y que no se sitúan en el desenlace son: los ofidios, la salamandra, los prostíbulos que se sitúan en la calle de las Sierpes, y que son constatados por A. Egido. ${ }^{82}$

Pero, como hemos adelantado, el motivo más importante en la obra de Tirso es el del fuego. Este elemento es el que relaciona directamente a don Juan con su antecedente mítico, Ixión, el cual, recordemos, es castigado a estar atado a una rueda envuelta en llamas que no para de moverse nunca. Al igual que en don Juan, en Ixión el fuego aparece en su castigo. Además, el fuego también está presente en los mitos de los antecedentes de Fausto: en la historia de Ícaro, es el sol el que quema las alas del hijo de Dédalo y provoca su muerte; en la historia de Faetonte, es un rayo de Zeus -

\footnotetext{
78 C. Marlowe, p. 177.

79 Hernández Valcárcel, C., "La «comida alegórica» en la literatura española", Archivum: Revista de la Facultad de Filología, Tomo 34-35, 1984-1985, pp. 35-50.

80 Ibidem, p. 178.

81 A. Egido, op. cit.

${ }^{82}$ A. Egido, op. cit.
} 
Júpiter el que alcanza al hijo del Sol y lo mata; y en el caso de Prometeo es el robo del fuego el que causa el castigo del benefactor de los hombres.

Por su parte, el fuego juega un importantísimo papel en la tragedia de Tirso. Francisco Florit nos dice al respecto:

Algo parecido sucede con la presencia en la obra de los conceptos de «abrasarse» y «quemarse». Aquí lo que se da es una traslación irónica desde el sentido metafórico al sentido literal, pues el burlador, que suele expresar - muy en la línea de la tradición poética - su pasión sexual a través de la imagen del fuego y del ardor, morirá abrasado interiormente, siendo sus últimas palabras: «QQue me quemo! ¡Que me abraso! ¡Muerto soy!».83

El fuego juega un papel irónico, pues de ser el elemento de la pasión sexual se va a convertir en el símbolo de la condenación de don Juan.

Como elemento sexual símbolo de la pasión podemos proponer el siguiente ejemplo extraído de la obra. Tisbea le dice a don Juan en pleno proceso de conquista: «Mucho fuego prometéis» ${ }^{84}$, pero este fuego pronto va a pasar de ser un elemento positivo a ser el elemento mediante el cual la pescadora revela su burla, es decir, el fuego de su pasión se transforma en el fuego de su vergüenza e ira:

¡Fuego, fuego, que me quemo,/ que mi cabaña se abrasa! [...] Mi pobre edificio queda/ hecho otra Troya en las llamas,/ que después que faltan Troyas,/ quiere amor quemar cabañas. [...] ¡Fuego, zagales, fuego, agua, agua!/ ¡Amor, clemencia, que se abrasa el alma!/ ¡Ay choza, vil instrumento/ de mi deshonra, y mi infamia!/ ¡Cueva de ladrones fiera,/ que mis agravios ampara! ${ }^{15}$

Esta transformación del elemento fuego es un eco anticipado del fuego que va a castigar a don Juan («iQue me quemo! ¡Que me abraso!/ ¡Muerto soy!»). ${ }^{86}$ Es también significativo que en la obra de Tirso no aparezca mencionado el infierno como tal, sino sólo mediante el fuego, mientras que en la obra de Marlowe sí que se usa la palabra «infierno»y otros sinónimos como «averno».

Para concluir con el motivo del fuego en El burlador de Sevilla me parece conveniente citar lo que dice al respecto Ignacio Arellano:

\footnotetext{
83 T. Molina, op. cit., prólogo de Francisco Florit Durán, p. 32-33.

84 Ibidem, p. 94, vv. 986-987, 990-993, 998-1003.

85 Ibidem, p. 179, vv. 2770-2771.

86 T. Molina, op. cit., prólogo de Ignacio Arellano, pp. 25-26.
} 
las imágenes de Troya se relacionan con el motivo del fuego y su poder destructivo, que resulta a su vez símbolo de la pasión amorosa [...] y del castigo eterno. De nuevo, las reiteraciones de imágenes y vocablos refuerzan la coherencia estructural: su fuego será para Tisbea expresión del amor [...] pero también de su desesperación en el abandono deshonroso [...] Don Juan, responsable de estos dos fuegos perecerá a su vez abrasado, en justa correspondencia. [...] el discurso de Tisbea integra toda una serie de motivos premonitorios que expresan irónicamente lo frágil de su libertad y preparan el marco de la burla. ${ }^{87}$

Pero si el fuego es importante, hay un elemento que une mucho más a ambas obras: la presencia constante de presagios, augurios, avisos y advertencias que intentan prevenir a los protagonistas de las consecuencias de sus actos.

En este sentido, destacan en ambas obras los personajes que actúan como complementos de los protagonistas, ya que tanto Mefistófeles como Catalinón, que por un lado, aunque con muchas diferencias, se encuentran al servicio de sus respectivos amos y les ayudan en sus planes, por otro lado, avisan en muchas ocasiones a Fausto y a don Juan del terrible castigo que les espera si continúan como hasta ahora. En Mefistófeles, personaje en el que sorprende que intente prevenir a Fausto ya que se trata de un demonio, podemos observar todo esto en el siguiente ejemplo y en los que ya hemos presentado:

Por su ambicioso orgullo e insolencia/ lo arrojó Dios de la faz de los cielos ${ }^{88}$

le dice Mefistófeles a Fausto sobre Lucifer.

Por su parte, en la obra de Tirso, Catalinón es el personaje que más veces previene a don Juan sobre lo que está haciendo y sobre sus consecuencias. Ello podemos verlo en los siguientes ejemplos:

Los que fingís y engañáis/ las mujeres de esa suerte,/ lo pagaréis en la muerte. ${ }^{89}$

No lo apruebo./ Tú pretendes que escapemos/ una vez, señor, burlados;/ que el que vive de burlar/ burlado habrá de escapar/ (pagando tantos pecados)/ de una vez. ${ }^{90}$

\footnotetext{
87 C. Marlowe, p. 65.

88 T. Molina, p. 89-90, vv. 902-904. .

89 Ibidem, p. 111, vv. 1348-1354.

90 Ibidem, p. 140, vv. 1974-1977.
} 
Mira lo que has hecho, y mira/ que hasta la muerte, señor,/ es corta la mayor vida;/ que hay tras la muerte imperio. ${ }^{91}$

Pero no sólo estos personajes van a ser los que adviertan a Fausto y a don Juan del terrible castigo que les espera si no dominan sus soberbias actitudes. En la obra de Marlowe aparecen personajes alegóricos o simbólicos que constantemente avisan a Fausto y que, en muchas ocasiones, a diferencia de don Juan, le hacen dudar y plantean un conflicto. Así, la primera referencia que encontramos es la del coro, que mediante el ejemplo de Ícaro nos avisa a los espectadores del destino de Fausto. Enseguida tenemos un personaje alegórico, como es el Ángel Bueno que intenta que Fausto elija el camino de Dios para que no se condene. Pero el personaje más importante en cuanto a las advertencias es el enigmático personaje del Anciano, cuya única función es la de intentar convencer a Fausto de su arrepentimiento. Ello lo podemos ver en el siguiente fragmento:

¡Ay, mi buen Fausto! Abandona este arte perverso,/ esta magia que hechizada llevará tu alma al infierno y te privará por siempre de salvarte. ${ }^{92}$

También en la obra nos encontramos con presagios que no son parte de la intervención de personajes, sino hechos simbólicos o ejemplos que deben servir a Fausto para no perseverar en sus intenciones diabólicas. En primer lugar nos encontramos con la coagulación de la sangre de Fausto en el momento en que va a firmar el pacto con el demonio. En la misma línea nos encontramos con el aviso que aparece en el brazo del protagonista cuando ya ha firmado el documento: «Homo fuge!» También es otro presagio el eco que Fausto oye en sus oídos y que le dice: «¡Tú estás condenado, Fausto!» Y para finalizar este repaso, es conveniente hablar de una ironía en la que no cae Fausto, pero sí el espectador. Cuando éste va a ver el desfile de los Siete Pecados Capitales, se compara con Adán al contemplar el Paraíso:

Tan agradable me será contemplarlos como a Adán/ le fue el Paraíso el primer día de la creación..$^{93}$

pero no se da cuenta de que su pecado es el mismo que el de Adán y que también por ello va a ser castigado igual que el personaje bíblico.

Por su parte, don Juan es avisado no sólo por Catalinón, sino por otros personajes de la obra, como Tisbea, quien lo previene de la existencia de Dios («Advierte,/ mi

\footnotetext{
${ }_{91}$ C. Marlowe, op. cit., p. 163.

92 Ibidem, p. 91.

93 T. Molina, op. cit., p. 91, vv. 943-944.
} 
bien, que hay Dios y que hay muerte») ${ }^{94}$ o le avisa de que si no cumple su promesa Dios le castigará («Esa voluntad te obligue,/ y si no, Dios te castigue»). ${ }^{95} \mathrm{O}$ también es prevenido por su propio padre, don Diego, quien le dice a su hijo que su castigo es inexorable:

Traidor, Dios te dé el castigo/ que pide delito igual./ Mira que, aunque al parecer/ Dios te consienta y aguarda,/ su castigo no se tarda,/ y que castigo ha de haber/ para los que profanáis/ su nombre; que es jüez fuerte/ Dios en la muerte. ${ }^{96}$

y que, cuando ve que sus palabras no causan el esperado efecto, decide dejar el castigo de su hijo en manos de Dios («Pues no te vence castigo/ con cuanto hago y cuanto digo,/ a Dios tu castigo dejo». $)^{97}$

Por último, también el leitmotiv de la obra, el «¡Tan largo me lo fiáis!», es utilizado por los músicos para introducir el auténtico sentido y moraleja de la obra: «que no hay plazo que no se llegue ni deuda que no se cumpla».

Como vemos, tanto Fausto como El burlador se construyen sobre un efecto dramático in crescendo de augurios, presagios, avisos y advertencias.

\section{LA CRÍTICA SOCIAL}

Tanto en la obra de Marlowe como en la de Tirso va a ser muy importante el tema de la crítica, aunque con diferencias. Mientras que la crítica en Fausto está orientada hacia la religión católica, representada por el Papa y por las jerarquías de dicha Iglesia, en El burlador la crítica está orientada hacia el poder real y los individuos sobre los que descansa éste.

En La trágica historia de la vida y la muerte del doctor Fausto la crítica religiosa aparece en el episodio en el que Fausto y Mefistófeles viajan hasta el palacio del Papa, situándonos en pleno cisma de Occidente, ya que nos encontramos con los enfrentamientos entre el emperador Federico Barbarroja y el Papa Adriano IV. El emperador alemán era protestante y el Papa católico, por lo que se enfrentan por cuestiones religiosas y, además, por medio de ellos se establece una lucha entre el poder religioso y el monárquico. Recordemos que anteriormente la excomunión de un Papa representaba para un rey que sus súbditos ya no debían seguir obedeciéndole.

\footnotetext{
94 Ibidem, p. 92, vv. 959-961.

95 Ibidem, p. 115, vv. 1436-1444.

96 Ibidem, p. 116, vv. 1463-1465.

97 C. Marlowe, op. cit., pp. 105-106.
} 
El enorme poder que posee el Papa se observa en su siguiente intervención:

Depondremos por ello al Emperador (Federico Babarroja había nombrado Papa a Alejandro III)/ y anatematizaremos a quien a él se someta,/ y tú y él permaneceréis excomulgados/ y apartados del favor de la Iglesia/ y de toda la comunión de los Santos. ${ }^{98}$

Para Marlowe el poder terrenal del Papa era desmesurado, ya que disponía de un poder excesivo que utilizaba a su antojo, como podemos observar en la intervención de éste:

¿No se nos ha otorgado todo poder sobre la tierra? [...] para atar y desatar, encerrar, juzgar y condenar,/ desvelar y ocultar, o para lo que nos plazca./ Así que tú y él y todo el orbe habréis de inclinaros.../ o tened por cierto que nuestro terrible anatema/ descenderá riguroso como las penas del infierno. ${ }^{99}$

La actitud soberbia del Papa y su poder ilimitado, que utiliza sin justicia ni misericordia, sólo para su personal beneficio, representa en la obra la crítica más feroz hacia el Catolicismo.

Por su parte, el abuso de poder es también uno de los temas secundarios de la obra de Tirso de Molina. La crítica en dicha obra va contra aquéllos que ayudan a don Juan a actuar impunemente sin recibir su merecido castigo, mientras otros son acusados de sus actos.

En primer lugar nos encontramos con el personaje de don Pedro, tío del protagonista, mano derecha del rey de Nápoles quien, tras descubrir que es su sobrino el que ha gozado de Isabela en el palacio del rey, no duda en dejarle escapar y, de manera mucho más cínica, de culpar de ello al duque Octavio, al que, por supuesto, no duda en prevenir de la decisión del rey de arrestarlo, para que huya, mostrando otra vez un gran cinismo.

Por su parte, según Ignacio Arellano, los reyes no son precisamente ejemplos de buenos gobernantes. ${ }^{100}$ En el caso del rey de Nápoles, subraya que éste no indaga sobre lo sucedido en el palacio, sino que acepta lo que le dice don Pedro sin más. Por su parte, el rey don Alfonso actúa con ineptitud y, además, no castiga a don Juan cuando debe. Este rey «casamentero y grotesco» se limita a intentar emparejar a los personajes para casarlos.

\footnotetext{
98 Ibidem, p. 107.

99 T. Molina, prólogo de Ignacio Arellano, pp. 38-43.

100 T. Molina, prólogo de Ignacio Arellano, p. 51.
} 
Otro personaje que, al mismo tiempo que advierte a don Juan de su próximo castigo, le ayuda a cometer sus excesos, es su padre, don Diego, que es el "privado del rey" don Alfonso y que oculta hechos y encubre a su hijo.

Por lo que a las burlas de don Juan se le une la impunidad que disfruta por su condición social y política.

Esta crítica social se ve sobre todo en el trato que don Juan le da a Batricio, según nos dice Arellano:

Si hay un personaje en quien la crítica social contra la injusta actuación del poderoso pueda concentrarse, nadie mejor en El burlador de Sevilla que el desdichado Batricio. ${ }^{101}$

Todos estos elementos hacen cuestionarse a Arellano si en la obra existe una crítica de Tirso al falso honor social, mientras que Wardropper, citado por Arellano, asegura que el tema central de la obra es «la falibilidad de la justicia humana, que provoca la actuación de la justicia divina» ${ }^{102}$, pero ante esto cabe preguntarnos: ¿realmente el final de la obra supone la restitución del equilibrio mediante las bodas? Puesto que ninguna de ellas está libre de culpa y de burla. Ello plantea un final problemático y atípico en el teatro de la época.

Asimismo, debemos señalar brevemente el carácter negativo de todos los personajes que aparecen en la obra: Tisbea es una desdeñosa que es engañada, Isabela pretendía deshonrar el palacio del rey, Aminta es culpable por sus ambiciones al igual que su padre, el marqués de la Mota no es precisamente un ejemplo de virtudes, el duque Octavio podría recurrir a la boda con Isabela y no a la cita clandestina en el palacio del rey de Nápoles... Respecto al resto de personajes ya acabamos de ver cómo encubren los actos de don Juan. Quedan, por tanto, tan sólo dos casos especiales, el de doña Ana y el de don Gonzalo.

En el caso de doña Ana se plantea el problema de si ella reconoce a don Juan o no, y si llega a ser mancillada por éste o no. Lo que sí que no deja lugar a dudas, es que ella escribe el billete para el marqués de la Mota invitándolo a sus aposentos, lo que supone una actitud indigna para una mujer de la época y además es la causa indirecta de la muerte de su padre.

Muy diferente es el personaje de don Gonzalo, en el que algunos ven una especie de personificación diabólica. A pesar de ello, Don Gonzalo, se ha subrayado,

\footnotetext{
${ }^{101}$ T. Molina, prólogo de Ignacio Arellano, p. 51.

${ }^{102}$ Ibidem, p. 41.
} 
es el único personaje positivo de la obra, ya que su asesinato es cruel e inmerecido, y además es el personaje encargado de realizar la justicia divina al ejecutar el castigo de don Juan.

\section{CONCLUSIÓN}

Vistos todos estos elementos que hemos intentado analizar, no podemos dudar de que entre La trágica historia de la vida y la muerte del doctor Fausto de Christopher Marlowe y El burlador de Sevilla y convidado de piedra de Tirso de Molina existen semejanzas, todas ellas, por supuesto con matices. Lo que no podemos poner en duda es que tanto el Fausto de Marlowe como el don Juan de Tirso son el ejemplo del personaje soberbio que intenta transgredir las normas sociales y divinas creyendo que el castigo de sus actos no va a llegar nunca, o apurando los goces terrenales hasta que éste llega, pero que es finalmente castigado, puesto que representa según Aurora Egido el proceso de ascensión y desafío con la posterior caída. Es precisamente en su castigo donde Fausto y don Juan se identifican, y con ellos Adán y Eva, Ixión, Ícaro, Prometeo, Faetonte, Lucifer... y todos aquéllos que representan la caída.

\section{Bibliografía}

Arellano, I., Historia del teatro español del siglo XVII, Madrid, Cátedra, 1995.

Calderon, P., El mágico prodigioso, Madrid, Cátedra, 2006.

Calderon, P., Las cadenas del demonio, http://www.trinity.edu/org/comedia/ calderon/Cadena.html [Fecha de consulta: 30/12/2010]

Dolfi, L., "El burlador burlado. Don Juan en el teatro de Tirso de Molina", en Varia lección de Tirso de Molina (Actas del Congreso Internacional, Pamplona, Universidad de Navarra, 27-29 de abril de 1998), Madrid - Pamplona, Instituto de Estudios Tirsianos, 1998.

Egido, A., "Sobre la demonología de los burladores", Cuadernos de Teatro clásico, 2, 1988. pp. 37-54.

HeRmenegildo, A., "Inversión dramática y forma narrativa: los romances del convite macabro", Cuadernos de Teatro clásico, 2, 1988. pp. 25-35.

Hernández VAlCÁrcel, C., “La «comida alegórica» en la literatura española”, Archivum: Revista de la Facultad de Filología, Tomo 34-35, 1984-1985, pp. 35-50.

MarLowe, C., La trágica historia de la vida y muerte del doctor Fausto, ed. J. C. Santoyo y J. M. Santamaría, Madrid, Cátedra, 2001.

Martín Nieto, E. (coord.), La Biblia, Madrid, San Pablo, 1989.

Martínez López, M., Y seréis como dioses. Estudio sobre Christopher Marlowe y doctor Fausto, Granada, Universidad de Granda, 1995. 
Mira de Amescua, A., El esclavo del demonio, en Teatro completo, Volumen IV, edición coordinada por Agustín de la Granja, Granada, Universidad de Granada, 2004.

MolinA, T., El burlador de Sevilla, ed. I. Arellano, Madrid, Austral, 1991.

MolinA, T., El burlador de Sevilla, ed. F. Florit, Madrid, Debolsillo, 2003.

Molina, T., El condenado por desconfiado, ed. C. Morón y R. Adorno, Madrid, Cátedra, 1978.

Morales, J. R., “El precedente mítico de Don Juan”, Cuadernos de Teatro clásico, 2, 1988. pp. 11-16.

Ovidio, Metamorfosis, ed. C. Álvarez y R. Ma Iglesias, Madrid, Cátedra, 1995.

Palomo, M. P., “La lexicalización de un mito”, Cuadernos de Teatro clásico, 2, 1988. pp. 17-24. 